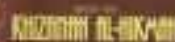
$\frac{1}{-2}$ $+$ $-\frac{1}{-1}$ $-=$

\title{
ANALISIS FAKTOR PENYEBAB KERUSAKAN BAHAN PUSTAKA DI PERPUSTAKAAN SMP NEGERI 4 SUNGGUMINASA, GOWA
}

\author{
St. Ummu Salamah*
}

Pengutipan: Salamah, St. U. (2016). Analisis Faktor Penyebab Kerusakan Bahan Pustaka di SMP Negeri 4 Sungguminasa. Jurnal Ilmu Perpustakaan, Informasi,danKearsipan Khizanah AlHikmah, 3(2), 194-204

*Pengelola Jurnal Elektronik UIN Alauddin di UPT Perpustakaan UIN Alauddin (ummusalamah589@gmail.com)

\section{ABSTRAK}

Kerusakan bahan pustaka merupakan hal yang sering dialami oleh setiap perpustakaan, khususnya pada jenis perpustakaan sekolah. Penelitian ini bertujuan untuk mengetahui faktor penyebab kerusakan bahan pustaka dan cara mengatasi penyebab kerusakan bahan pustaka di Perpustakaan SMP Negeri 4 Sungguminasa, Gowa. Penelitian ini bersifat deskriptif dengan pendekatan kualitatif yang memberikan gambaran mengenai apakah faktor penyebab kerusakan bahan pustaka serta bagaimana cara mengatasi faktor penyebab kerusakan bahan pustaka. Teknik pengumpulan data dilakukan dengan observasi mengamati langsung di lapangan, serta wawancara kepada pengelola perpustakaan sekolah. Hasil penelitian menunjukkan bawah faktor penyebab kerusakan bahan pustaka di Perpustakaan SMP Negeri 4 Sungguminasa terbagi atas tiga yaitu: kerusakan yang diakibatkan oleh siswa-siswi, kerusakan yang diakibatkan oleh banjir, dan kerusakan yang diakibatkan oleh serangga yakni kecoa dan rayap. Adapun penanggulangan yang dilakukan pustakawan yaitu pemberian sanksi kepada pemustaka, penjilidan terhadap koleksi yang terlepas dari sampul, memindahkan semua koleksi yang terkena percikan air dan membuat laporan agar pihak yang berwajib membantu menangani kerusakan tersebut, pembersihan debu di rak dan pemberian kapur barus keselasela buku.

Kata Kunci: Kerusakan Bahan Pustaka, Perpustakaan sekolah, Pelestarian bahan pustaka

\section{ABSTRACT}

The damaged of library collections must be concerned by all type of libraries. It always occured in library, particularly in school libraries. The study will investigate factors that damaged library collections and ways to solve such a case in the library of SMP 4 Sungguminasa, Gowa (a secondary school located in Gowa, South Sulawesi). The data were gathred through direct observations and interviews with staf in the library. The study found that there were kinds of damaged of library collection, which were 1) caused by studens, 2) caused by floods, and 3) caused by insects. In terms of its preservation, the library have some solutions which were 1) determining strict penalties for the library users who have damaged the collections, 2) binding library materials, 3) setting the library room, 4) maka a report to the school authoritative to care of library school, 5) cleaning routinely the library shelves.

Key Words: Library collection damages, Library school, Library collections preservation 


\section{PENDAHULUAN}

Bila mendengar istilah perpustakaan, dalam benak mereka akan tergambar sebuah gedung atau ruangan yang dipenuhi rak buku. Anggapan demikian tidaklah selalu salah karena bila dikaji lebih lanjut, kata dasar perpustakaan adalah pustaka. Dengan demikian, batasan perpustakaan ialah sebuah ruangan, bagian sebuah gedung, ataupun gedung itu sendiri yang digunakan untuk menyimpan buku dan terbitan lainnya yang biasanya disimpan menurut tata susunan tertentu untuk digunakan membaca, bukan untuk dijual (SulistyoBasuki, 1993: 3)

Sekolah merupakan tempat berlangsungnya kegiatan proses belajar mengajar para siswa dan tenaga pendidik. Tujuan diadakannya sekolah tidak lain yaitu mencerdaskan kehidupan bangsa sebagaimana tercantum di UndangUndang Sistem Pendidikan Nasional No. 20 tahun 2003 pasal 3 yaitu mencerdaskan kehidupan bangsa, mengembangkan manusia Indonesia seutuhnya yaitu manusia yang beriman dan bertakwa terhadap Tuhan Yang Maha Esa dan berbudi pekerti luhur, memiliki pengtahuan dan keterampilan, memiliki kesehatan jasmani dan rohani, kepribadian yang mantap dan mandiri serta tanggung jawab kemasyarakatan dan kebangsaa. Untuk mencapai tujuan pendidikan tersebut diperlukan banyak sarana dan prasarana salah satunya adalah tersedianya perpustakaan sekolah.

Perpustakaan sekolah merupakan salah satu sarana pendukung sekolah yang wajib disediakan oleh sekolah di mana tempat perpustakaan tersebut berada. Peran utama sebuah perpustakaan sekolah yaitu menyimpan dan menyediakan bahan-bahan pustaka dan ruang baca yang nyaman bagi para pengunjungnya.

Penyelenggaraan perpustakaan sekolah itu sendiri mengacu kepada Undang-Undang Nomor 2 Tahun 1989 tentang Sistem Pendidikan Nasional. Di mana pada pasal 35 tersebut dikemukakan bahwa salah satu sumber belajar yang amat penting tetapi bukan satu-satunya adalah perpustakaan, yang harus memungkinkan para tenaga kependidikan dan para peserta didik memperoleh kesempatan untuk memperluas dan memperdalam pengetahuan melalui membaca buku dan koleksi lain yang diperlukan (Yusuf, Pawit M, $2005: 2$ )

Bahan pustaka atau koleksi perpustakaan menjadi hal yang penting untuk diperhatikan di sini, mengingat koleksi-koleksi tersebut akan digunakan oleh para pengunjungnnya. Supaya bahan pustaka dapat terus digunakan oleh yang membutuhkan, maka pihak perpustakaan harus menjaga keutuhan bahan pustaka tersebut. Hal ini dilakukan agar informasi dan ilmu pengetahuan yang berada di dalamnya tidak hilang dan rusak.

Perpustakaan SMP Negeri 4 Sungguminasa Gowa merupakan salah satu perpustakaan SMP di Kabupaten Gowa Sulawesi Selatan. Saat ini perpustakaan tersebut memiliki beberapa kegiatan, seperti kegiatan pengadaan, sirkulasi serta kegiatan perawatan. Kegiatan perawatan merupakan kegiatan yang paling sering dilakukan oleh pengelola perpustakaan sekolah ini dikarenakan tingginya tingkat kerusakan bahan pustaka yang ada di perpustakaan yang diperolah dari laporan pengelola 
perpustakaan. Hal ini menarik untuk diteliti.

Sebagaimana yang telah diungkapkan di atas bahwa, koleksi perpustakaan merupakan hal yang mendapat perhatian utama oleh setiap pengunjung perpustakaan. Oleh karena itu, penting untuk diketahui, sudah sepatutnya perpustakaan sekolah menyediakan koleksi-koleksi yang siap untuk dimanfaatkan oleh pengunjungnnya.

\section{RUMUSAN MASALAH}

Berdasarkan uraian singkat yang dikemukakan di atas, maka dapat dirumuskan masalah penelitian yaitu sebagai berikut:

a. Apa-apa saja faktor penyebab kerusakan bahan pustaka di Perpustakaan SMP Negeri 4 Sungguminasa, Gowa?

b. Bagaimana cara mengatasi faktor penyebab kerusakan bahan pustaka di Perpustakaan SMP Negeri 4 Sungguminasa, Gowa?

\section{TUJUAN DAN PENELITIAN}

MANFAAT

a. Tujuan Penelitian

Adapun yang menjadi tujuan dari penelitian ini yaitu,

1) Untuk mengetahui faktor penyebab kerusakan bahan pustaka di Perpustakaan SMP Negeri 4 Sungguminasa, Gowa.

2) Untuk mengetahuai cara mengetahui faktor penyebab kerusakan bahan pustaka di Perpustakaan SMP Negeri 4 Sungguminasa, Gowa.

\section{b. Manfaat Penelitian}

Adapun manfaat yang diharapkan dari penelitian ini yaitu penelitian ini dapat:

$\checkmark$ digunakan sebagai bahan rujukan oleh pengelola perpustakaan dalam pengembangan perpustakaan,

$\checkmark$ digunakan sebagai bahan rujukan oleh para peneliti lainnya yang tertarik untuk mengkaji hal yang sama

$\checkmark$ digunakan sebagai bahan pengambil kebijakan, khususnya buat pengelola perpustakaan SMP Negeri 4 Sungguminasa, Gowa.

\section{TINJAUAN TEORITIS}

\section{a. Definisi Analisis}

Analisis bisa diartikan sebagai kajian yang dilaksanakan terhadap sebuah bahasa guna meneliti struktur bahasa tersebut secara mendalam. Sedangkan pada kegiatan laboratorium untuk memeriksa suatu zat atau cuplikan. Sedangkan dalam kamus besar ekonomi analisis yaitu melakukan evaluasi terhadap kondisi dari pos-pos atau ayatayat yang berkaitan dengan akuntansi dan alasan-alasan yang memungkinkan tentang perbedaan yang muncul.

Analisis adalah kegiatan berfikir untuk menguraikan suatu keseluruhan menjadi komponen, sehingga dapat mengenal tanda-tanda komponen, hubungannya satu sama lain dan fungsi masing-masing dalam satu keseluruhan yang terpadu (Komaruddin: 1994). 


\section{b. Definisi Bahan Pustaka}

Dalam Kamus Besar Bahasa Indonesia bahan diartikan segala sesuatu yang dapat dipakai atau diperlukan untuk tujuan tertentu. Sedangkan bacaan memiliki arti buku, yang dibaca. Sedangkan pustaka mempunyai arti buku (Gunawan Rony K, 2009).

Bahan pustaka memiliki peran penting dalam sebuah perpustakaan sekolah karena dapat mendukung proses belajarmengajar di sekolah tersebut. Kurangnya jumlah bahan pustaka atau kualitas yang tidak baik pada bahan pusataka sebuah perpustakaan juga akan mempengaruhi proses belajar mengajar.

\section{c. Pengertian Perpustakaan Sekolah}

Perpustakaan sekolah merupakan salah satu sarana dan fasilitas penyelenggaraan pendidikan sehingga setiap sekolah semestinya memiliki perpustakaan. Perpustakaan Sekolah berada di lingkungan sekolah dan sepenuhnya dikelola oleh sekolah yang bersangkutan (Sutartono, 2005)

\section{d. Penyebab kerusakan Bahan Pustaka}

Pemeliharaan bahan pustaka bukanlah hal baru bagi pustakawan. Namun tugas pelestarian bukanlah tugas yang mudah . Para pustakawan terutama di negara tropis seperti Indonesia ini dihadapkan pada berbagai musuh dalam menjaga bahan pustaka. Musuh bahan pustaka antara lain manusia, tikus, serangga serta berbagai bencana alam (Karmidi Martoatmodjo, 2009: 2.1).

Bahan pustaka yang terbuat dari kertas merupakan bahan yang mudah terbakar, mudah sobek, mudah rusak karena pengguna, mudah timbul noda dan sebagainya. Kekuatan kertas semakin lama semakin menurun, akibatnya kertas akan berubah warna menjadi kuning kecoklatan dan akhirnya menjadi rapuh dan hancur. Walaupun demikian cepat atau lambat proses kerusakan pada kertas tergantung juga dari mutu kertas dan iklim daerah di mana kertas itu berada serta cara perawatannya.

Jenis perusak bahan pustaka di daerah yang beriklim sedang atau tropis berbeda dengan perusak bahan pustaka dari daerah beriklim dingin begitu pula cara penanggulangannya. Di daerah yang beriklim tropis memiliki perusak bahan pustaka yang lebih banyak dan ganas dari daerah yang beriklim dingin.

Kerusakan bahan pustaka secara garis besar dapat disebabkan oleh beberapa hal yaitu:

\section{1) Kerusakan oleh Alam}

Kerusakan bahan pustaka salah satunya disebabkan oleh alam. Faktor alam yang dapat merusak bahan pustaka adalah cahaya, udara, air, dan api. Cahaya adalah suatu bentuk energi elektromagnetik yang berasal dari radiasi cahaya matahari dan lampu listrik. Cahaya sangat penting untuk menerangi ruang perpustakaan.Tapi di dalam cahaya terdapat sinar ultra violet yang mampu merusak kertas dan merubah warna. Kerusakan yang terjadi karena pengaruh ultra violet adalah memudarnya tulisan, sampul buku, dan warna bahan cetakan (Rajak, $1992: 5$ )

Selain itu bahan pustaka dapat rusak dari bencana alam, misalnya banjir dan kebakaran.Kedua bencana itu dapat mengakibatkan bahan pustaka menjadi 
rusaak cukup berat, dalam waktu yang singkat dan bahan pustaka yang relative banyak.

\section{2) Kerusakan oleh Manusia}

Manusia sebagai musuh dan kawan bahan pustaka apabila: Manusia dalam hal ini pemakai dapat merupakan lawan atau juga kawan. Pemakai perpustakaan dapat menjadi kawan bilamana membantu pengamanan buku dengan cara menggunakan bahan pustaka secara cermat dan hati-hati. Pengunjung akan menjamin musuh buku bilamana memperlakukan buku dengan kasar sehingga robek dan rusak (SulistiyoBasuki, 1991:272).

\section{3) Kerusakan oleh Bintang}

Hal yang sangat perlu diperhatikan oleh pustakawan dalam memelihara bahan pustaka adalah binatang pengerat dan serangga, karena bahan pustaka terdiri dari kertas dan perekat yang merupakan sumber makanan bagi mahluk tersebut. Jamur juga dapat merusak bahan pustaka oleh sebab itu bahan pustaka harus dipelihara agar tidak habis.

\section{e. Pencegahan dan Perbaikan Kerusakan Bahan Pustaka}

\section{1) Pencegahan}

Dalam mencegah kerusakan bahan pustaka hendaklah disesuaikan dengan faktor-faktor kerusakan yang terjadi pada bahan pustaka, misalnya:

- mencegah kerusakan karena pengaruh cahaya

- mencegah kerusakan karena pengaruh suhu dan kelembaban udara

- mencegah kerusakan karena debu

- mencegah kerusakan karena manusia

\section{f. Perbaikan kerusakan bahan pustaka}

Definisi perbaikan (restoration) dinyatakan Dureau (1990:25) sebagai berikut: "merupakan teknik-teknik dan pertimbangan-pertimbangan yang digunakan oleh petugas teknis yang bertugas memperbaiki bahan pustaka dan arsip yang rusak akibat waktu, pemakaian dan faktor lainnya."

Ada beberapa cara atau teknik dalam memperbaiki bahan pustaka, tergantung pada kondisi bahan pustaka yang akan diperbaiki, misalnya sebagai berikut:

\section{1) Menambal}

Menambal atau menutup bagian yang berlubang dapat dilakukan dengan kertas Jepang, kertas "hand made" dan perekat kanji atau CMC. Menambal juga dapat dilakukan dengan bubur kertas (pulp), atau menggunakan kertas tissue yang berperekat dan dibantu dengan alat "tacking iron".

\section{2) Laminasi}

Laminasi dilakukan bagi bahan pustaka yang tidak dapat diperbaiki dengan menjilid, menambal dan menyambung. Biasanya bahan pustaka yang dilaminasi karena sudah berwarna kuning, coklat, kotor dan berbau apek. Laminasi maksudnya adalah menutupi satu lembar kertas diantara dua lembar bahan penguat. Laminasi ini dapat dilaksanakan secara manual yakni laminasi dengan tangan dan laminasi modern dengan menggunakan mesin dimana bahan laminasi sudah didesain dalam bentuk siap pakai.

\section{3) Penjilidan}


Penjilidan merupakan salah satu kegiatan yang sangat penting dalam perpustakaan karena penjilidan merupakan proses akhir dari perbaikan. Berbagai hal yang dapat membuat buku rusak, antara lain karena usia, kondisi ruang penyimpanan yang tidak memenuhi syarat, cara pemakaian yang relatif sering dan salah, dimakan serangga atau jamur dan lain-lain. Ragam kerusakan yang terjadi misalnya bahan pustaka menjadi rapuh, berlubang, sobek, jahitan dan cover terlepas dan berbagai bentuk kerusakan lain.

\section{METODOLOGI PENELITIAN}

\section{a. Jenis Penelitian}

Metode yang digunakan dalam penelitian ini adalah metode penelitian kualitatif. Pengertian penelitian kualitatif dapat diartikan sebagai penelitian yang menghasilkan data deskriptif mengenai kata-kata lisan maupun tulisan, dan tingkah laku yang dapat diamati dari orang-orang yang diteliti (Bagong Suyanto, Sutinah, 2005: 166)

\section{b. Sumber Data}

Adapun jenis dan sumber data yang diperlukan dalam penelitian adalah:

\section{1) Data Primer}

Data Primer yaitu data yang diperoleh langsung dari sumber data yakni bapak Kamaruddin yang menjabat sebagai Kepala perpustakaan SMP Negeri 4 Sungguminasa dan ibu Alfirayanti bagian pelayanan di Perpustakaan SMP Negeri 4 Sungguminasa.

\section{2) Data Sekunder}

Data Sekunder yaitu data yang sumbernya diperoleh dari beberapa buku dan hasil penelitian yang relevan dengan masalah penelitian ini.

\section{c. Instrumen Penelitian}

Dalam melakukan penelitian penulis menggunakan instrumen penelitian berupa tabel wawancara, yakni sejumlah daftar yang berisi pertanyaan yang akan diberikan kepada informan sebagai upaya untuk mendapatkan keterangan yang dibutuhkan sesuai dengan judul yang diteliti. SmartPhone Blackberry, yakni alat yang digunakan peneliti untuk merekam dan mendokumentasi suatu penelitian sesuai dengan judul yang akan diteliti yakni analisis faktor penyebab kerusakan bahan pustaka di perpustakaan SMP Negeri 4 Sungguminasa.

\section{d. Teknik Pengumpulan Data}

Dalam mengumpulkan data ada dua cara yang dipakai, yakni :

1) Library Research (data kepustakawanan): yaitu pengumpulan data atau penyelidikan melalui perpustakaan dengan membaca buku-buku dan karya ilmiah yang ada hubungannya dengan permasalahan yang dibahas.

2) Field Research (data Lapangan): yaitu berdasarkan hasil yang diperoleh melalui penelitian lapangan dalam artian penulis mengadakan penelitian di dalam masyarakat melalui orang-orang yang dianggap tahu mengenai hal tersebut, yang berhubungan 
dengan permasalahan yang akan dibahas.

\section{HASIL PENELITIAN DAN PEMBAHASAN}

Berikut ini akan diuraikan hasil penelitian sekaligus pembahasan yang berdasarkan rumusan masalah yang telah disebutkan sebelumnya.

\section{a. Faktor-faktor Penyebab Kerusakan Bahan Pustaka di Perpustakaan SMP Negeri 4 Sungguminasa Gowa}

Kerusakan bahan pustaka menjadi hal yang lumrah pada setiap jenis perpustakaan. Beberapa di antara perpustakaan tersebut memiliki tingkat kerusakan yang tinggi dibanding dengan perpustakaan lainnya. Tentu saja ada halhal yang mengakibatkan kerusakan bahan pustaka tersebut. Berikut ini akan diuraikan faktor-faktor penyebab kerusakan bahan pustaka di Perpustakaan SMP Negeri 4 Sungguminasa Gowa.

Dari hasil penelitian menunjukkan bawah ada berberapa faktor penyebab kerusakan bahan pustaka yang terjadi di Perpustakaan SMP Negeri 4 Sungguminasa Gowa yakni sebagai berikut:

\section{1) Kerusakan bahan pustaka yang diakibatkan oleh manusia}

Kerusakan bahan pustaka yang diakibatkan oleh manusia yang ada di Perpustakaan SMP Negeri 4 Sungguminasa yakni bersumber dari pemustakanya sendiri, seperti merobek dan mencoret-coret bahan pustaka yang ada di perpustakaan, bahkan ada beberapa buku yang terlepas dari sampulnya.
Berdasarkan wawancara kepada kepala perpustakaan dan juga pengelola perpustakaan, menyatakan bahwa banyak siswa-siswi yang tidak menghargai koleksi perpustakaannya sendiri, bahkan hingga merobek dan mencoret-coret isi buku tersebut. Ini menyangkut karakter siswa-siswi yang tentu berasal dari latar belakang keluarga atau lingkungan yang berbeda-beda.

Dari jawaban di atas, dapat dikatakanan bahwa hal tersebut merupakan hal yang memang sering terjadi di perpustakaan sekolah. Di usia siswa-siswi seperti ini terkadang memang ada tindakan-tindakan yang kurang dipahami oleh para siswa-siswi sebagai tindakan yang tidak beretika. Mencoret terlebih lagi merobek bahan pustaka tentu saja dapat merugikan orang lain.

2) Kerusakan bahan pustaka yang diakibatkan oleh alam

Letak perpustakaan sekolah juga menjadi hal yang perlu diperhitungkan di sebuah sekolah. Bencana alam seperti banjir terkadang menjadi penyebab hancurnya bahan pustaka. Begitu pula yang pernah dirasakan oleh Perpustakaan SMP Negeri 4 Sungguminasa Gowa yakni terkena banjir dan terkena percikan air hujan yang datang dari ventilasi jendela.

Penyebab kerusakan ini hampir terjadi dibanyak perpustakaan, khususnya yang berada di lokasi yang sering terkena banjir. Hal ini tak dapat terhindari namun dapat dilakukan pencegahan sedini mungkin.

3) Kerusakan bahan pustaka yang diakibatkan oleh binatang pengerat (seperti kecoa dan rayap buku) 
Binatang pengerat seperti kecoa dan rayap buku merupakan musuh setiap pustakawan atau pengelola perpustakaan. Binatang-binatang pengerat seperti ini jika tidak diantisipasi secepat mungkin dapat memberikan kerusakan yang parah terhadap koleksi perpustakaan.

Dari komentar pengelola perpustakaan yang menyatakan bahwa banyak terdapat koleksi perpustakaan yang dimakan oleh rayap. Bahkan, rak perpustakaan yang juga terbuat dari kayu menjadi santapan rayap tersebut

Selain itu, terkadang ada siswa-siswi yang meletakkan sisa makanan atau minuman yang mereka bawa ke dalam perpustakaan yang akhirnya dapat memancing binatang seperti kecoa dan semut. Penyebab ini mungkin sering terabaikan oleh banyak pengelola perpustakaan.

\section{b. Upaya Penanggulangan Penyebab Kerusakan Bahan Pustaka di Perpustakaan SMP Negeri 4 Sungguminasa Gowa}

Dari hasil yang telah didapatkan di atas tentang faktor penyebab kerusakan bahan pustaka di Perpustakaan SMP Negeri 4 Sungguminasa Gowa maka selanjutnya peneliti akan membahas mengenai upaya penanggulangan penyebab kerusakan bahan pustaka di Perpustakaan SMP Negeri 4 Sungguminasa Gowa.

Perbaikan kerusakan bahan pustaka di Perpustakaan SMP Negeri 4 Sungguminasa salah satu upaya yang dilakukan pustakawan untuk melestarikan bahan pustaka agar dapat dipergunakan lebih lama. Untuk mengatasi kerusakan bahan pustaka maka pustakawan akan menyesuaikan faktor-faktor apa yang menjadi penyebab kurusakan bahan pustaka tersebut.

Adapun upaya yang dilakukan pengelola perpustakaan dalam mengatasi penyebab kerusakan bahan pustaka di perpustakaan SMP Negeri 4 Sungguminasa yakni sebagai berikut:

\section{1) Sanksi}

Menerapkan sanksi kepada pemustaka yang merusak bahan pustaka dan mengganti buku yang dirusak oleh pemustaka sesuai dengan bahan pustaka yang dirusak atau dengan membayar sesuai dengan harga buku yang dirusak sehingga pustakawan yang akan membeli dan menggantikan bahan pustaka yang telah dirusak pemusataka dan menjilid buku yang terlepas dari sampul buku.

2) Menempatkan buku pada posisi yang aman

Adapun upaya yang dilakukan pustakawan dalam mengatasi faktor kerusakan bahan pustaka yang diakibatkan oleh alam di Perpustakaan SMP Negeri 4 Sungguminasa yaitu dengan memindahkan semua buku-buku yang terkena percikan air dan membuat laporan sehingga pihak yang berwajib dapat membantu mengatasi kerusakan tersebut .

3) Pembersihan dan kapur barus

Adapun upaya yang dilakukan pustakawan dalam mengatasi faktor kerusakan bahan pustaka yang diakibatkan oleh serangga di Perpustakaan SMP Negeri 4 Sungguminasa yaitu membersihkan debu yang ada dirak buku kemudian 
membungkus kapur barus dan meletakkannya di sela-sela buku sehingga serangga tersebut tidak lagi merusak dan upaya yang dilakukan pustakawan mengatasi lemari yang rusak dimakan rayap yakni hanya menunggu lemari tersebut digantikan oleh pihak sekolah.

\section{KESIMPULAN}

Berdasarkan hasil penelitian yang penulis lakukan dengan cara mewawancara pustakawan/pegawai perpustakaan yakni 2 orang, tentang faktor penyebab kerusakan bahan pustaka di Perpustakaan SMP Negeri 4 Sungguminasa dan cara mengatasi faktor penyebab kerusakan bahan pustaka di SMP Negeri 4 Sungguminasa. Untuk itu penulis mengemukakan beberapa kesimpulan sebagai berikut:

Faktor kerusakan bahan pustaka di Perpustakaan SMP Negeri 4 Sungguminasa.

Ada bebrapa faktor penyebab kerusakan bahan pustaka yang ada di perpustakaan SMP Negeri 4 Sungguminasa yakni :

Kerusakan bahan pustaka yang diakibatkan oleh manusia

Kerusakan bahan pustaka yang diakibatkan oleh alam

Kerusakan bahan pustaka yang diakibatkan oleh serangga.

Upaya penanggulangan faktor penyebab kerusakan bahan pustaka di perpustakaan SMP Negeri 4 Sungguminasa.
Upaya penanggulangan yang diakibatkan oleh manusia yaitu dikenakan sangsi kepada pemustaka yang merusak bahan pustaka dan mengganti buku yang dirusak oleh pemustaka sesuai dengan bahan pustaka yang dirusak atau dengan membayar sesuai dengan harga buku yang dirusak sehingga pustakawan yang akan membeli dan menggantikan bahan pustaka yang telah dirusak pemusataka dan menjilid buku yang terlepas dari sampul buku .

Upaya penanggulangan yang diakibatkan oleh alam yaitu dengan memindahkan semua buku-buku yang terkena percikan air dan membuat laporan sehingga pihak yang berwajib dapat membantu mengatasi kerusakan tersebut .

Upaya penanggulangan yang diakibatkan oleh serangga yaitu membersihkan debu yang ada dirak buku kemudian membungkus kapur barus dan meletakkannya di sela-sela buku sehingga serangga tersebut tidak lagi merusak dan upaya yang dilakukan pustakawan mengatasi lemari yang rusak dimakan rayap yakni hanya menunggu lemari tersebut digantikan oleh pihak sekolah

\section{DAFTAR PUSTAKA}

Bagong Suyanto, Sutinah. 2005 Metode Penelitian Sosial : sebagai alternatif pendekatan. Cet. 5; Jakarta: Kencana.

Cinta Lestari. 2013. : "Pengertian Analisis", Blok Cinta Lestari. http:/ / pengertianbahasa.blogspot.com/20 13/02/pengertiananalisis.html?m=1 (12 November 2014). 
Darmono. 2001. Manajemen dan Tata Perpustakaan Sekolah. Cet. 1; Jakarta : Gramedia.

Dirjen Pendidikan Tinggi. 1994. Depdikbud Perpustakaan Perguruan Tinggi, Buku Pedoman, Edisi. II; Jakarta: Dekdikbud RI.

Ema Julianti. 2011. "Skripsi". Perawatan Bahan Pustaka Pada Perpustakaan Kampus LP3I Gajah Mada Sumatera Utara. http:/ / repository.usu.ac.id / bitstream/123456789/28959/4/C hapter\%20II.pdf (24 September 2014).

Gunawan Rony K. 2001. Kamus Lengkap Bahasa Indonesia. Edisi I Terbaru; Surabaya Terbit Terang.

Hildawati Almah. 2012. Pemilihan dan Pengembangan Koleksi

Perpustakaan, Makassar: Alauddin University.

Ibrahim Bafadal. 2001. Pengelolaan Perpustakaan Sekolah. Cet 1 ; Jakarta : Rineka Cipta.

Kamus Besar bahasa Indonesia. Diakses di http:/ / kamusbahasaindonesia.org (09 Mei 2013).

Kartini Kartono. 1996. Pengantar Metodologi Riset Sosial, Bandung: Mandar Maju

Komaruddin. 1994. "Pengertian Bahan Bacaan dan Bahan Pustaka", Blok Ridwan Nur Arifin. http:/ / coretanridwan.blogspot.co $\mathrm{m} / 2013 / 06 /$ pengertian-bahanbacaan-dan-pengertian-bahanpustaka.html?m=1 (13 November 2014).

Lasa HS. 2002. Manajemen Perpustakaan Madrasah \& Sekolah . Yogyakarta; Pinus Book Publish.

Karmidi Martoadmodjo. 2009. Pelestarian Bahan Pustaka : Jakarta. Universitas terbuka.
Moh Nasir. 2005. Metodologi Penelitian. Bogor : Ghalia Indonesia

Pawit M Yusuf. 2013. Pedoman Penyelenggaraan Perpustakaan Sekolah. Jakarata; Kencana.

Perpustakaan Nasional RI. 1995 Petunjuk Teknis Pelestarian Bahan Pustaka. Jakarta : Perpustakaan Nasional Republik Indonesia.

Putri Ayuningtyas. 2013. “Jurnal Ilmu Perpustakaan", Analisis Faktor Kerusakan Koleksi Bahan Pustaka dan Cara Penanganannya di SMP Mardisiswa 1 Semarang. Vol. 2, No. 4.http://portalgaruda.org/index.p hp?ref=browse\& mod= $=$ viewarticle\&article $=142753$ (16 Januari 2015)

Muhammad Qosim . 2006. “Pengantar Kearsipan", Makalah. http:/ / bpadjogja.info / file/1d938b00eb7dff2f6d201167aff c9b36.pdf. (09 Mei 2013).

Muhammadin Rajak. 1992. Pelestarian Bahan Pustaka dan Arsip, Jakarta : Program Pelestarian Bahan Pustaka dan Arsip.

Rahayuningsih. 2007. Pengelolaan Perpustakaan. Yogyakarta: Graha Ilmu.

Ridwan Nur Arifin. 2013. "Pengertian Bahan Bacaan dan Bahan Pustaka", Blok Ridwan Nur Arifin. http:/ / coretanridwan.blogspot.co $\mathrm{m} / 2013 / 06 /$ pengertian-bahanbacaan-dan-pengertian-bahanpustaka.html?m=1 (12 November 2014).

Soebradjin S. 1983. "Pemeliharaan Bahan Pustaka" dalam berita Perpustakaan Sekolah.

Sulistyo-Basuki. 1993. Pengantar Ilmu Perpustakaan. Jakarta : Gramedia Pustaka Utama. 
Sutarno NS. 2006. Manajemen Perpustakaan: Suatu Pendekatan Praktik, Jakarta: CV. Sagung Seto.

Sutartono. 2005. "Peran Perpustakaan Sekolah sebagai sarana Pendidikan dalam PencapaianTujuan di Bidang Pendidikan MDGs", Perpustakaan Digital.

http://www.pustaka.ut.ac.id/dev2

5/index.php?option=com_content \&view=article\&id=2144:peranperpustakaan-sekolah-sebagaisarana-pendidikan-dalampencapaian-tujuan-di-bidangpendidikan-mdgs-

2015\&catid $=124 \&$ Itemid $=302$

November 2014).

Vonny Destia dan Ardoni. 2012 Jurnal. "Ilmu Informasi Perpustakaan dan Kearsipan". Pemeliharaan dan Pelestarian Bahan Pustaka di Perpustakaan SMA Negeri 7 Padang. Vol. 1, No. 1. http:// portalgaruda. org/index.php?ref=browse\&mod= viewarticle\&article $=101306$ (16 Januari 2015).

Wiradi. 2006. "Pengertian Analisis", Blok Cinta Lestari.

http:/ / pengertianbahasa. blogspot.com/2013/02/pengertian -analisis.html?m=1 (13 November 2014).

Yuyu Yulia dan Janti Gristinawati Sujana. 2009. Pengembangan Koleksi. Jakarta : Universitas Terbuka. 